\title{
Effect of landcover/land-use changes on water availability in and around Ruti Dam in Nyazvidzi catchment, Zimbabwe
}

\author{
W Gumindoga1*, DT Rwasoka², N Ncube ${ }^{3}$, E Kaseke $^{4}$ and T Dube ${ }^{5}$ \\ 'University of Zimbabwe, Dept of Civil Engineering, PO Box MP 167, Harare, Zimbabwe \\ ${ }^{2}$ Upper Manyame Subcatchment Council, Box 1892, Harare, Zimbabwe \\ ${ }^{3}$ Chinhoyi University of Technology, Dept of Environmental Engineering, P.O. Box 7724 Chinhoyi Zimbabwe \\ ${ }^{4}$ ZAMCOM, Samora Machel Avenue, Harare, Zimbabwe \\ ${ }^{5}$ University of the Western Cape, Private Bag X17, Bellville, 7535, South Africa
}

\begin{abstract}
The aim of this study was to quantify the upstream land-use and landcover changes and assess their effect on Ruti Dam levels and water availability in Nyazvidzi catchment. Remote-sensing techniques, hydrologic modelling and statistical inference were applied. Spatial landcover dynamics were derived from Landsat satellite data for the years 1984, 1990, 1993, 1996, 2003, 2008 , and 2013 using the maximum likelihood classification technique. Results showed that forests and shrubs decreased by $36 \%$ between 1984 and 2013 whilst cultivated areas increased by 13\% over the same period. The HEC-HMS rainfall-runoff model was used to simulate steamflow for the Nyazvidzi catchment, Zimbabwe. For the calibration period (2000-2001), a satisfactory Nash-Sutcliffe efficiency (NSE) model peformance of 0.71 and relative volume error $\left(\mathrm{RV}_{\mathrm{E}}\right)$ of $10 \%$ were obtained. Model validation (1995-1997) gave a NSE of 0.61 and $\mathrm{RV}_{\mathrm{E}}$ of $12 \%$. We applied the Mann-Kendall trend test to assess for monotonic trends in runoff over the study period and the results showed that there were significant decreases in observed runoff at Station E140 (monthly time scale) and at Stations E62 and E140 (seasonal time scale). Results showed that the wet season (Nov-Feb) had higher mean water balance values with an excess runoff of $8.12 \mathrm{~mm} / \mathrm{month}$. The dry season (AprilSept) had lower mean water balance values, with the lowest at $0.04 \mathrm{~mm} / \mathrm{month}$. Strong positive relationships $\left(r^{2}\right)$ between dam levels and land-use changes were obtained as follows: bare (0.95), cultivation (0.76) and forests (0.98). The relationship between runoff generated and land-use changes was found to be relatively weaker $(0.54$ for forests, 0.51 for bare and 0.14 for cultivation). Findings of this study underscore the relevance of applying hydrological models, remote sensing and statistical inference in quantifying and detecting environmental changes, as well as how they affect the availability and the quality of water resources in space and time.
\end{abstract}

Keywords: HEC-HMS, land-use, landcover, Mann-Kendall, Nyazvidzi, remote sensing, Ruti Dam

\section{INTRODUCTION}

Land-use change, potentially, has significant impacts on catchment hydrologic and ecological processes (Chen et al., 2009; Wijesekara et al., 2012) over a range of temporal and spatial scales. As such, obtaining land-use change information in hydrological catchments is very important for land-use planning and integrated water resource management (Cihlar et al., 2005). This is because any slight modification of landcover can affect runoff generation and flow patterns through the modification of interception, infiltration, overland flow and evaporation processes (Hundecha et al., 2004; Vivoni, 2007). Better assessment and understanding of land-use change impacts on catchment hydrologic processes also helps in predicting the availability of already scarce water resources in arid and semiarid regions. This is a critical issue in catchment planning and management (Chen, Xu 2009; Wang et al., 2007), in order to meet the various competing and often conflicting water demands.

The use of water for agricultural production from smallscale reservoirs in water-scarce regions requires innovative and sustainable research, proper management and equitable allocation of the resource (Mufute et al., 2008). In semi-arid regions, many small reservoirs capture surface runoff during the rainy season in order to make water available during the dry season. For the local population, reservoirs are important

\footnotetext{
To whom all correspondence should be addressed.

e-mail: wgumindoga@gmail.com

Received 9 January 2017; accepted in revised form 15 January 2018
}

water sources, as they help them cope with droughts (Onema et al., 2006). However, meeting increasing demands on limited water resources is complicated in catchments undergoing environmental changes, such as land-use and landcover change (LULCC). The challenge of managing such scarce water resources in catchments undergoing LULCC and uncontrolled population growth is further compromised by the unavailability of hydro-meteorological data. Sometimes, where the data are available, the data have long gaps that make it difficult to make critical decisions and perform analyses that can aid well-informed water resource planning and management. At a catchment scale, such impacts affect hydrological processes which, in turn, significantly influence the ecosystem, environment and local economy (Ali et al., 2010).

In Zimbabwe, the Nyazvidzi catchment where the Ruti Dam is situated is undergoing environmental changes, the impacts of which are not yet fully understood. The Ruti Dam provides water for primarily sustaining sugar irrigation plantations in the Lowveld, although recently a small-scale irrigation scheme has been commissioned around the dam. The new scheme supports 120 families, with an area of 60 ha. The catchment is no exception to the challenges of LULCC and its impact on water availability in and around the dam. However, to the best of our knowledge, little is known about LULCC changes in the Nyazvidzi catchment and their relation to runoff generation, the water balance of the Ruti Dam and yield. In this study area, irrigation water demands and upstream LULCC could be influencing the variation in water availability in and around the dam. So far, only a few studies 
in Zimbabwe have assessed impacts of LULCC on catchment hydrology (Lorup and Mazvimavi, 1998; Dube 2014). However, none of these studies have performed a detailed characterization and quantification of historical LULCC and their impact on the availability of water resources at catchment scale. Some of the studies in Zimbabwe have relied on the use of rudimentary methods to assess the impacts of land conversion on runoff generation and water availability. General surveys and field-based assessments, statistical techniques and hydrological model simulations have been used (Lørup et al., 1998), but these methods are limited, without remote-sensing data for characterization of land-use/ landcover change.

Geographical information systems (GIS) and remote sensing (RS) technologies can be a viable tool to quantify historical land conversions over space and time. Nowadays satellite-based hydro-meteorological data such as rainfall, temperature and evapotranspiration, can be quantified over gauged and ungauged catchments and these can be used as forcings to hydrological models. Alternative methods have been developed in recent years which provide rapidly available hydrological data over large areas based on remote-sensing techniques. Satellite data can be used to: derive terrain parameters using freely available elevation data (Maathuis and Wang, 2006; Gumindoga et al., 2011), estimate soil moisture (Horváth, 2002; Meier et al., 2011), estimate rainfall (Habib et al., 2012; Haile et al., 2013), quantify evapotranspiration (Rwasoka et al., 2011; Rientjes et al., 2013) and determine landcover parameters (Dube et al., 2014; Gumindoga et al., 2014a; Gumindoga et al., 2014b).

Therefore, the objective of this study was to quantify upstream land-use and landcover changes affecting water availability in the Nyazvidzi catchment and Ruti Dam using remote-sensing techniques. Specifically, this research: (i) quantified the historical changes in land-use and landcover change in the Nyazvidzi catchment, (ii) analysed hydrometeorological trends in the catchment, (iii) modelled streamflow for the downstream Nyazvidzi outlet and (iv) related the changes in land-use and landcover to the dam volume and flows.

\section{STUDY AREA}

The Nyazvidzi catchment is located between the Runde and Lower Save catchments. The main river is the Nyazvidzi River, which is a tributary of the Save River (Fig. 1). Rainfall over the catchment is fairly scarce, with an average of $600 \mathrm{~mm} /$ yr (Muyambo and Lacroix, 2004), and is distributed over one rainy season that extends from November to March of the following year. The temperature range is $\sim 10^{\circ} \mathrm{C}$, with a mean monthly maximum of $24^{\circ} \mathrm{C}$ and a minimum of $14^{\circ} \mathrm{C}$. The Upper Nyazvidzi catchment is dominated by red loam soils, while the lower catchment is dominated by loose alluvial soils. The catchment is covered by grassland vegetation, sparse forests and shrubs, and most of the area is cultivated. The Nyazvidzi catchment is subject to: seasonal droughts, prolonged mid-season dry spells and at times an unreliable commencement of the rainy season. Irrigation thus plays an important role in sustaining crop production, with the utilization of Ruti Dam (Fig. 1), which supplies water to Ruti Irrigation Scheme. The dam has a full supply capacity of 127 $\mathrm{x} 10^{6} \mathrm{~m}^{3}$, and was constructed in 1976 . In the year 2000 , the embankment of the dam was raised by $1.6 \mathrm{~m}$, increasing the capacity of the dam to $151.6 \times 10^{6} \mathrm{~m}^{3}$. The resulting increase in capacity $\left(24.7 \times 10^{6} \mathrm{~m}^{3}\right.$ from $125.9 \times 10^{6} \mathrm{~m}^{3}$ to $\left.151.6 \times 10^{6} \mathrm{~m}^{3}\right)$ enhanced the useable yield by $6.9 \times 10^{6} \mathrm{~m}^{3}$ at the $10 \%$ risk level (Muyambo et al., 2003). Based on current planning and allocation procedures, $36 \times 10^{6} \mathrm{~m}^{3}$ is committed to downstream Chisumbanje Sugarcane Irrigation schemes and $0.9 \times 10^{6} \mathrm{~m}^{3}$ is used for irrigation by local farmers.

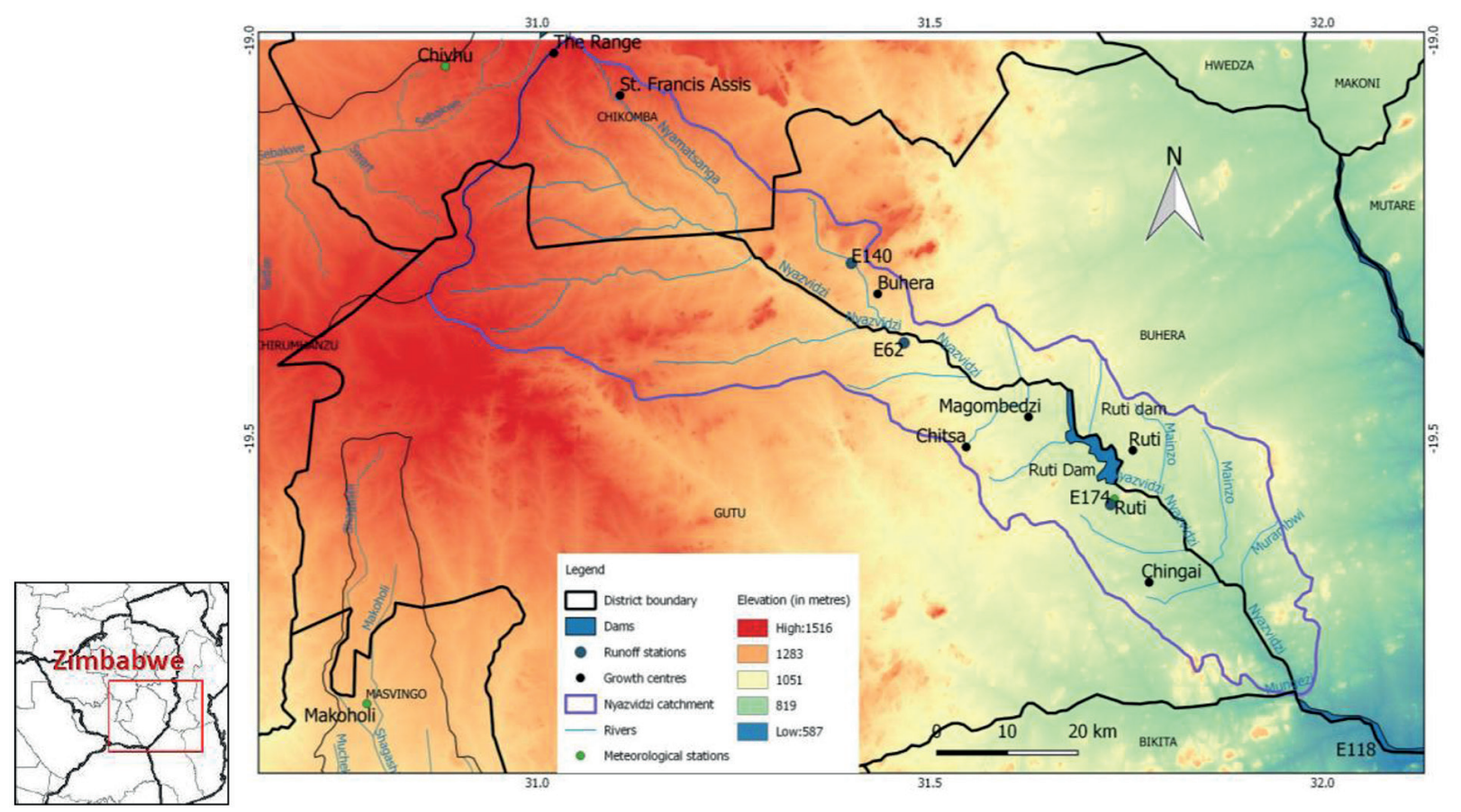

Figure 1

Location of the study site 


\section{MATERIALS AND METHODS}

\section{Data availability}

\section{Image acquisition and pre-processing}

Cloud-free Landsat images used for the detection of landcover changes, were sourced from the online Landsat data archive (http://glovis.usgs.gov/). The images were downloaded for the June-September period which coincides with the cool dry season of Zimbabwe. Landsat MSS, TM and ETM (30 m resolution) images for the period 1984-2011 were downloaded and used for digital image classification in the Integrated Land and Water Information System (ILWIS) software. A total of 250 ground control points (GCPs) were collected using a global positioning system (GPS). This study made use of multispectral pseudo-natural colour band combinations of 5, 4 and 3 (Landsat 7) and 6, 5, and 4 (Landsat 8 ). The pseudo-natural colour combination is considered the best band combination for landcover activity detection (Calera Belmonte et al., 1999). The wavelength ranges and usage are shown in Table 1 . The images were processed in the ILWIS software.

The selection of a sufficient number of representative training sample plots for each class is critical in image classification (Foody et al., 2004; Lu et al., 2004). A total of 102 training sample plots were selected. The maximum likelihood classifier (MLC), algorithm which is a parametric classifier that assumes normal or near-normal distribution for each feature of interest, was used to classify the Landsat TM images into thematic maps. The MLC is based on the probability that a pixel belongs to a particular class, taking the variability of classes into account by using the covariance matrix (Shalaby and Tateishi, 2007). Table 2 provides a description of the classes used in this study.

\begin{tabular}{|l|c|c|c|}
\hline \multicolumn{4}{|c|}{ TABLE 1 } \\
\hline Band & Spectral $(\mu \mathrm{m})$ & Spectral & Use \\
\hline 3 & $0.63-0.69$ & Visible & Water absorption \\
\hline 4 & $0.76-0.90$ & Near-infrared & Vegetation \\
\hline 5 & $1.55-1.75$ & Mid-infrared & Soil humidity \\
\hline 6 & $2.08-2.350$ & Mid-infrared & Geological features \\
\hline
\end{tabular}

TABLE 2

Description of the landcover classes used in the study

\begin{tabular}{|l|l|}
\hline Class & Description \\
\hline Water & $\begin{array}{l}\text { Area occupied by water such as rivers } \\
\text { and dams }\end{array}$ \\
\hline Bare & Area not put to use \\
\hline Cultivated & Area used for farming \\
\hline Forest and shrubs & $\begin{array}{l}\text { Area covered with sparse to dense } \\
\text { woody species such as shrubs and trees }\end{array}$ \\
\hline Settlement & $\begin{array}{l}\text { Area covered by structures such as } \\
\text { buildings }\end{array}$ \\
\hline Grass & Area predominately covered with grass \\
\hline
\end{tabular}

The accuracy of the classification was assessed using ground control points. An average of 40 ground control points were taken for each land-use and landcover class that is either grassland, water, bare areas and cultivated land, using a GPS receiver. The ground control points were used to draw up a confusion matrix, from which the percentage accuracy levels were derived. The ground control points were compared to corresponding points on the classified maps is establishing the confusion matrix.

\section{Hydrometeorological data}

Discharge data were obtained from the Zimbabwe National Water Authority (ZINWA) for the E118, E62, E140 and E174 gauging stations for the period 1992-2006. Meteorological data that included daily rainfall and temperature for the period 1991 to 2012 was provided by the Meteorological Services Department of Zimbabwe. The daily areal rainfall of Nyazvidzi catchment was estimated using the Thiessen polygon method. Station Thiessen weights as calculated in ILWIS software were as follows: Chivhu 0.42, Makoholi 0.24, ZINWA (Ruti Dam) 0.34

\section{Trends in hydrometeorological data}

\section{The Mann-Kendall test}

The Mann-Kendall trend test was used to test for the presence of monotonic trends $(p<0.05)$ in rainfall, temperature and runoff data. The tests were carried out at $5 \%$ level of significance. The major variables for test interpretation were the $p$-value and the Sen's slope. The test statistic, $S$, is estimated using the formula:

$$
S=\frac{\sum_{i=1}^{n=1} \sum_{j=i+1}^{n} \operatorname{sgn}\left(Y_{j}-Y_{i}\right)}{\delta_{s}}
$$

where

$\delta_{\mathrm{s}}=$ Standard deviation

$n=$ Number of data sets

$Y_{\mathrm{j}}$ and $Y_{\mathrm{i}}=$ Data values in consecutive periods 1 if $Y_{\mathrm{i}}-Y_{\mathrm{i}}>0$

$\operatorname{sgn}\left(Y_{\mathrm{j}}-Y_{\mathrm{i}}\right)=0$ if $Y_{\mathrm{j}}-Y_{\mathrm{i}}=0$ -1 if $Y_{j}-Y_{i}<0$

A positive sgn value in Eq. 2 indicates an increasing trend in the data, whilst a negative $s g n$ value represents a decreasing trend (Mann, 1945; Kendall, 1975).

\section{Rainfall-runoff simulation}

In order to estimate runoff from both the gauged and the ungauged catchments, a rainfall-runoff model (HEC-HMS) was used to simulate flows. However, before using the model, input parameters had to be estimated from fieldwork data and parameter transfer from the nearby gauged catchment to the ungauged catchments following Gumindoga et al. (2016).

\section{Catchment parameter comparison}

To provide a sound hydrological basis for transferring the validation parameters from Upper Nyazvidzi (gauged) to the ungauged lower Nyazvidzi catchment, a similarity in catchment hydrological response needed to be established. This was done through comparison of the physical catchment characteristics based on data obtained from the hydro-processing of a 
digital elevation map (DEM) of the study area in a GIS. The DEM hydro-processing yielded the catchment area, drainage network, drainage density, upstream and downstream elevation, catchment perimeter, and longest flow length and catchment outlets. Therefore, an advanced space-borne thermal emission radiometer (ASTER) DEM of $30 \mathrm{~m}$ resolution covering the study area was retrieved free of charge from the website of the Global Aster GDEM (http://www.gdem.aster.ersdac.or.jp/). Rainfall data from 3 different stations in the study area were also compared to see if they varied significantly over the catchment.

After conducting the physical parameter comparison, the HEC-HMS model was then used to simulate flows based on inputs of rainfall, catchment area, lag time, peaking coefficient and runoff coefficient. The HEC-HMS model was selected because it has the Snyder unit hydrograph transformation subroutine specifically for ungauged catchments, making it ideal for use in this study (Sreenivasulu and Bhaskar, 2010).

\section{Transformation methods}

Transformation methods control the time of concentration of water into the river channel. The Snyder unit hydrograph developed in 1938 was used (Snyder, 1938; USACE, 2008) to calculate catchment lag and the runoff coefficient based on the rational method.

$$
Q_{\mathrm{p}}=0.28 C I A
$$

where

$Q_{\mathrm{p}}=$ Peak discharge $\left(\mathrm{m}^{3} / \mathrm{s}\right)$

$C=$ Runoff coefficient

$I=$ Rainfall intensity $(\mathrm{mm} / \mathrm{h})$

$A=$ Catchment area $\left(\mathrm{km}^{2}\right)$

$0.28=$ Conversion factor

\section{Catchment time lag}

The catchment lag time $t_{\mathrm{p}}$ was calculated using Eq.4:

$$
t_{\mathrm{p}}=C C_{\mathrm{t}}\left(L L_{\mathrm{c}}\right)^{0.3}
$$

where

$t_{\mathrm{p}}=$ Basin lag time $(\mathrm{h})$

$\stackrel{\mathrm{p}}{\mathrm{C}}=$ Conversation constant of 0.75

$C_{\mathrm{t}}=$ Runoff coefficient from gauged catchment

$L=$ Longest channel from outlet $(\mathrm{km})$

$L_{c}=$ Length of the main stream from the outlet to the catchment centroid $(\mathrm{km})$

$L$ and $L_{\mathrm{c}}$ were calculated from the DEM hydro-processing procedure.

\section{Meteorological model for HEC-HMS}

Thiessen method, area-averaged daily rainfall for the years 1992-2012, mean monthly evaporation and gauge weights of the three rainfall stations were used as input for the HEC-HMS meteorological model. The Penman-Monteith method was used for estimating daily evaporation (2001-2003). The meteorological stations that were used were Chivhu, Makoholi and Ruti (ZINWA).

\section{Assessing model efficiency}

In this study, two model performance indicators were used, namely, the Nash-Sutcliffe efficiency coefficient (NSE) and the relative volume error $\left(\mathrm{RV}_{\mathrm{E}}\right)$.
The NSE was used to assess the predictive power of rainfallrunoff model (Nash and Sutcliffe, 1970). It is defined as:

$$
\mathrm{E}=1-\frac{\sum_{\mathrm{t}=1}^{\mathrm{T}}\left(\mathrm{Q}^{0-\mathrm{t}}-\mathrm{Q}^{\mathrm{m}-\mathrm{t}}\right)^{2}}{\sum_{\mathrm{t}=1}^{\mathrm{T}}\left(\mathrm{Q}^{0-\mathrm{t}}-\mathrm{Q}^{\mathrm{mean}}\right)^{2}}
$$

where:

$Q_{\mathrm{o}}=$ observed discharge $\left(\mathrm{m}^{3} / \mathrm{s}\right)$

$Q_{\mathrm{m}}=$ modelled discharge $\left(\mathrm{m}^{3} / \mathrm{s}\right)$

$Q_{\mathrm{ot}}=$ observed discharge at time $t\left(\mathrm{~m}^{3} / \mathrm{s}\right)$

NSE values range from $-\infty$ to 1 . An efficiency of $1(E=1)$ corresponds to a perfect match of modelled discharge to the observed data. An efficiency of $0(E=0)$ indicates that the model predictions are as accurate as the mean of the observed data, whereas an efficiency less than zero $(E<0)$ occurs when the observed mean is a better predictor than the model or, in other words, when the residual variance (described by the numerator in the expression above), is larger than the data variance (described by the denominator).

The second performance measure, $\mathrm{RV}_{\mathrm{E}}$ was used for quantifying the volume errors. $\mathrm{RV}_{\mathrm{E}}$ can vary between $+\infty$ and $-\infty$ but performs best when a value of 0 is generated, since no difference between simulated and observed discharge occurs (Janssen and Heuberger, 1995). An $\mathrm{RV}_{\mathrm{E}}$ between $+5 \%$ or $-5 \%$ indicates that a model performs well, while an $\mathrm{RV}_{\mathrm{E}}$ between $+5 \%$ and $+10 \%$ and $-5 \%$ and $-10 \%$ indicate a model with reasonable performance.

$$
R V_{E}=\sum_{n=1}^{n}\left(\frac{Q_{s i m}-Q_{o b s}}{Q_{o b s}}\right)
$$

\section{Water balance for Nyazvidzi catchment}

The long-term monthly annual water balance for Nyazvidzi catchment for the period 1922-2013 was calculated by subtracting the HEC-HMS model-simulated losses from the precipitation. The computations were done for each month. The long-term water balance was determined as precipitation minus evaporation (P-E). In this study, it was formulated as precipitation minus losses using HEC-HMS model output.

\section{Relationship between landcover changes vs. dam levels and simulated flows}

The relationships amongst Ruti Dam levels, Nyazvidzi simulated discharge and LULCC for the period 1984-2013 were assessed using linear regression, with a focus on the $r$-square values and correlation coefficient. The analysis was performed by taking average yearly flows for 3 years surrounding the year of Landsat image acquisition following Gumindoga et al. (2014a) and Gumindoga et al. (2014b). For example, the area occupied by different landcover classes for the 1993 image was related to the average flow for 1992-1994. This was also done for the dam levels.

\section{RESULTS AND DISCUSSION}

\section{Land-use/landcover variation in the Nyazvidzi catchment}

Results of digital image classification showed that most of Nyazvidzi catchment is characterised by cultivated land, and bare fields, with scarce forest and shrub lands. Figure 2 a-e shows temporal variations of land-use and landcover in Nyazvidzi catchment from 1994 to 2013. 
It can be observed that forests and shrubs were concentrated in the central part of the catchment. This is because this area consists of commercial farming areas. Bare land is also dominant in the northern and south-western part of the catchment. It can also be observed that cultivated land is concentrated in the south-eastern and north-western parts of the catchment. Cultivation activities could be influenced by the communal areas that are dominant in the respective areas. Table 3 shows the absolute and percentage areas occupied by each landcover class.

Results show that forests and shrubs decreased from an area of $411.5 \mathrm{~km}^{2}$ in 1984 to $263.0 \mathrm{~km}^{2}$ in 2013 . This could be attributed to the increase in population in the rural districts of Gutu and Buhera from 1992-2012, which also has fuelled the demand for firewood as an energy source, causing deforestation of forests and shrubs (ZimStat, 2012a). This is supported by the fact that in Gutu and Buhera administrative districts that cover Nyazvidzi catchment, $90 \%$ and $94 \%$ of the households, respectively, use firewood as the main energy source for cooking (ZimStat , 2012b; ZimStat, 2012c). Population increases for Gutu and Buhera districts for the period 2002-2012 were 3 and $12 \%$, respectively.

Table 3 also shows that the cultivated area increased from $1105 \mathrm{~km}^{2}$ to $1247 \mathrm{~km}^{2}$, although the change is not as large as the change in forest and shrubs. The Nyazvidzi catchment receives average annual rainfall of between 400 and $600 \mathrm{~mm}$ (Muyambo and Lacroix, 2004), and therefore the cultivated area is expected not to change significantly since this is a semiarid area. In fact, the increase in cultivated area corresponds to changes in forest area. There is also an increase in grassland area from $528.65 \mathrm{~km}^{2}$ in 1984 to $804.7 \mathrm{~km}^{2}$ in 2011 . This could be the result of the decrease in forest and shrubs. Water areas also increased over time. This can be partly explained by the raising of the Ruti Dam wall in the year 2000. The wall was raised by $1.6 \mathrm{~m}$, which increased the capacity of the dam by $24.7 \times 10^{6} \mathrm{~m}^{3}$ from $125.9 \times 10^{6} \mathrm{~m}^{3}$ to $151.6 \times 10^{6} \mathrm{~m}^{3}$.

\section{Validation results}

The error or confusion matrix was used to quantify the level of accuracy in image classification. The confusion matrix was derived from the classfied map and field data in accuracy assessment. As shown in Table 4, accuracy (producer's accuracy) and reliability (user's accuracy) are above $65 \%$ which shows that the classification was satisfactory. Grassland $(G)$ and cultivated (CD) were the most difficult landcover classes to classify, as shown by only $57.1 \%$ of the groundtruthed grassland and cultivated pixels appearing as grassland and cultivated in the image. The most reliable class was water (100\%), meaning that $100 \%$ of the water pixels on the classified image actually represent water on the ground. The second most relaible class was forest \& shrubs (76.5\%).

\section{Trend analysis test on observed runoff}

Table 5 shows the results of the Mann-Kendall trend test for observed runoff for 3 stations in the catchment at monthly, seasonal and annual scales. At the monthly time scale, there is a decline in runoff at Stations E62 and E140. The decline is statistically significant $(p<0.05)$ at E140 only. At an annual scale, E62 and E118 show an increase in flows. The increasing trends are not significant at all stations. At a seasonal timescale, there are statistically significant decreasing trends in runoff at E62 and E140.

\section{Results of runoff simulation using HEC-HMS for the Upper Nyazvidzi sub-catchment}

Table 6 shows the model NSE and $\mathrm{RV}_{\mathrm{E}}$ values obtained at different stages during modelling runs. Only 5 runs were selected for the purposes of tabulation (Table 5). At least 62 runs were done during calibration of the model. Table 6 shows some of the simulation runs and parameter adjustments made so as to obtain favourable results for parameters to be used for validation and eventually simulating flow into Ruti Dam. Parameters shown in Table 5 on calibration gave a satisfactory NSE value of 0.7 and $\mathrm{RV}_{\mathrm{E}}$ of $19 \%$. These parameters were used to model streamflow into Ruti Dam. The relatively high $\mathrm{RV}_{\mathrm{E}}$ value was mainly due to a lag delay of the model on simulating the flow.

The model was calibrated with discharge for the period 2000 to 2001 from the Upper Nyazvidzi catchment. Figure 3 shows that the model gave a positive NSE of 0.71 , which is close to 1 . This indicates a good fit between observed and modelled flow data.

After calibration, the model was then validated for the period 1995 to 1997. The model gave a better performance

(Fig. 4) resulting in a relative error of $12 \%$ and a Nash-Sutcliffe model efficiency coefficient of 0.61 . NSE values range from $-\infty$ to 1 . Therefore the model perfomance for the Upper Nyazvidzi sub-catchment in the validation period is satisfactory.

\section{Water balance for Nyazvidzi catchment}

Long-term runoff simulation for the combined gauged (Upper Nyazvidzi) and ungauged catchments (Lower Nyazvidzi) was

\begin{tabular}{|c|c|c|c|c|c|c|c|c|c|c|}
\hline & & & esults of & $\begin{array}{r}\mathrm{T} \\
\text { poral }\end{array}$ & $\begin{array}{l}\text { E } 3 \\
\text { ation of }\end{array}$ & a and $c$ & & & & \\
\hline & & & & & & & & & & \\
\hline Class & & & & & & & & & & \\
\hline & $\mathrm{km}^{2}$ & $\%$ & $\mathrm{~km}^{2}$ & $\%$ & $\mathrm{~km}^{2}$ & $\%$ & $\mathrm{~km}^{2}$ & $\%$ & $\mathrm{~km}^{2}$ & $\%$ \\
\hline Bare & 522.7 & 20.3 & 438.9 & 17.1 & 291.8 & 11.3 & 244.6 & 9.5 & 244.7 & 9.5 \\
\hline Cultivated & 1105.2 & 43.0 & 1242.7 & 48.3 & 1209.3 & 47.0 & 1211.3 & 47.1 & 1247 & 48.5 \\
\hline Forest \& Shrub & 411.5 & 16.0 & 374.3 & 14.5 & 309.8 & 12.0 & 292.1 & 11.4 & 262.9 & 10.2 \\
\hline Grass & 528.7 & 20.5 & 506.6 & 19.7 & 747.7 & 29.1 & 811 & 31.5 & 804.7 & 31.3 \\
\hline Water & 4.9 & 0.2 & 10.6 & 0.4 & 14.4 & 0.6 & 14 & 0.5 & 13.6 & 0.5 \\
\hline Total & 2573 & 100.0 & 2573 & 100.0 & 2573 & 100.0 & 2573 & 100.0 & 2573 & 100.0 \\
\hline
\end{tabular}



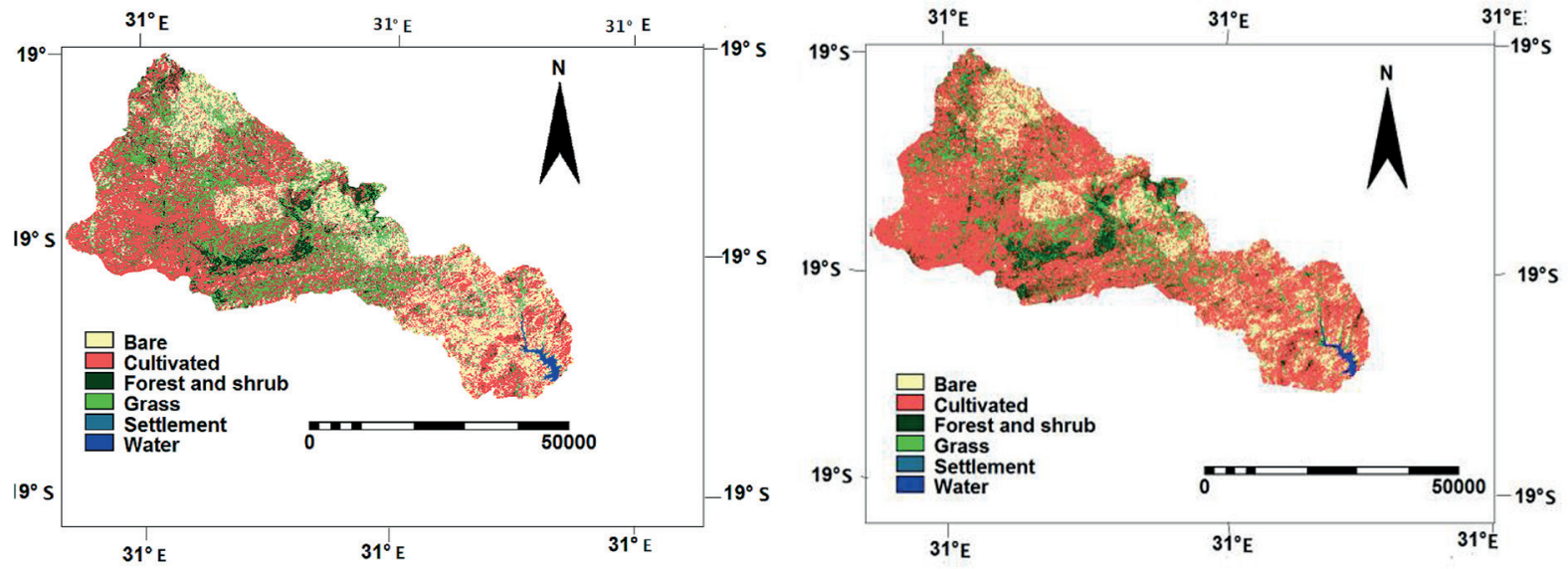

a) September 1984
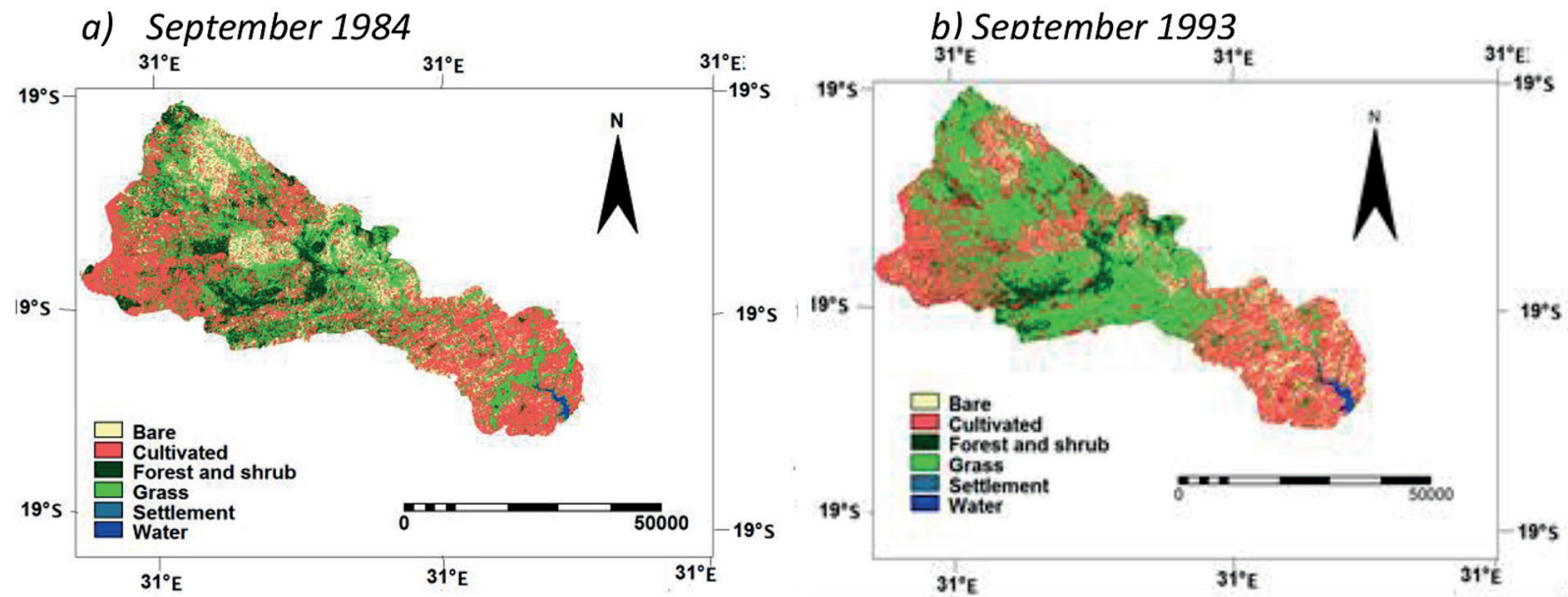

c) September 2003

d) September 2008

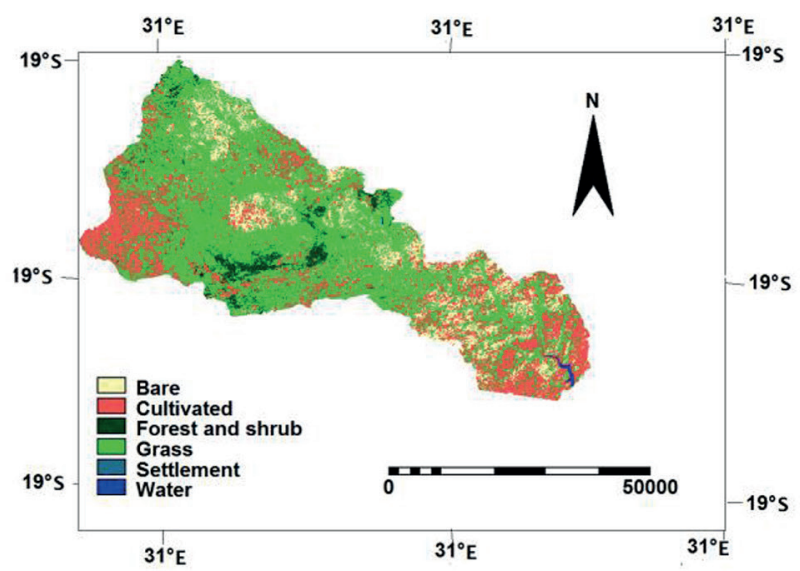

e) June 2013

Figure 2

Landcover changes for a) 1984, b) 1993, c) 2003 d) 1998 and e) 2013

carried out for the 1922-2013 period. Table 7 shows the longterm monthly annual water balance for Nyazvidzi catchment for the period 1922-2013, aggregated from daily timestep HEC-HMS simulations. The long-term water balance was determined as precipitation minus loss. Results show that the wet season (Nov-Feb) has higher mean water balance values with an excess runoff as high as $8.12 \mathrm{~mm} / \mathrm{month}$. The dry season (April-Sept) has lower mean water balance values, with the lowest at $0.04 \mathrm{~mm} /$ month. The standard deviation (SD) is also higher in the wet season than in the dry season, reflecting the higher variability of the water balance in the wet months. The coefficient of variation (CV) is comparatively higher in the dry months than the wet months. For example, CV (\%) is $199 \%$ in Sept and only $61 \%$ in November. This means that there is better reliability during the wet season than during the dry months. September has the highest CV which 
TABLE 4

Confusion matrix for validation of the classified map

\begin{tabular}{|l|c|c|c|c|c|c|}
\hline & BE & CD & W & FS & G & $\begin{array}{c}\text { Producer's } \\
\text { accuracy }\end{array}$ \\
\hline Bare (BE) & 15 & 2 & 0 & 0 & 3 & 75 \\
\hline Cultivated (CD) & 2 & 12 & 0 & 2 & 5 & 57.1 \\
\hline Water (W) & 0 & 0 & 20 & 0 & 0 & 100 \\
\hline Forest and shrub (FS) & 1 & 2 & 0 & 13 & 4 & 65 \\
\hline Grass (G) & 2 & 5 & 0 & 2 & 72 & 57.1 \\
\hline User's accuracy & 75 & 57.1 & 100 & 76.5 & 50 & 72 \\
\hline Average accuracy & $71.7 \%$ & & & & & \\
\hline Overall accuracy & $69.3 \%$ & & & & & \\
\hline
\end{tabular}

\begin{tabular}{|c|c|c|c|c|c|c|c|c|c|}
\hline \multicolumn{10}{|c|}{$\begin{array}{c}\text { TABLE } 5 \\
\text { Results of Mann-Kendall trend test on runoff }\end{array}$} \\
\hline & \multirow{2}{*}{$\begin{array}{l}\text { E62 } \\
\text { Monthly }\end{array}$} & \multirow{2}{*}{$\begin{array}{ll}\text { E62 } \\
\text { Annual }\end{array}$} & \multirow{2}{*}{\begin{tabular}{|l|} 
E62 \\
Seasonal \\
\end{tabular}} & \multirow{2}{*}{$\begin{array}{l}\text { E118 } \\
\text { Monthly }\end{array}$} & \multirow{2}{*}{$\begin{array}{l}\text { E118 } \\
\text { Annual }\end{array}$} & \multirow{2}{*}{$\begin{array}{l}\text { E118 } \\
\text { Seasonal }\end{array}$} & \multirow{2}{*}{$\begin{array}{l}\text { E140 } \\
\text { Monthly }\end{array}$} & \multirow{2}{*}{$\begin{array}{l}\text { E140 } \\
\text { Annual }\end{array}$} & E140 \\
\hline & & & & & & & & & Seasonal \\
\hline Kendall's tau & -0.012 & 0.042 & -0.008 & 0.084 & 0.101 & 0.097 & -0.312 & -0.39 & -0.353 \\
\hline S & -14.11 & 32 & -76 & 9677 & 90 & 902 & -11885 & -106 & -1057 \\
\hline $\operatorname{Var}(\mathrm{S})$ & $1.2 \times 10^{7}$ & $7.3 \times 10^{3}$ & - & $1.2 \times 10^{7}$ & $9.1 \times 10^{3}$ & - & $7.5 \times 10^{6}$ & $1.6 \times 10^{3}$ & - \\
\hline$p$-value (Two tailed) & 0.688 & 0.717 & 0.872 & 0.006 & 0.351 & 0.034 & $<0.001$ & 0.009 & -0.0001 \\
\hline Sen's slope & -50 & 0.011 & 0.01 & 0.004 & 0.012 & 0.037 & -50.5 & -0.017 & 0 \\
\hline Confidence interval & -1.19 & -7.74 & - & -1.61 & -12.7 & - & -0.08 & -0.37 & -0.012 \\
\hline
\end{tabular}

\begin{tabular}{|c|c|c|c|c|c|c|c|}
\hline \multicolumn{8}{|c|}{$\begin{array}{c}\text { TABLE } 6 \\
\text { NSE and } \text { RV }_{\mathrm{E}} \text { values }\end{array}$} \\
\hline Parameter & Calibration & Validation & Run 1 & Run 2 & Run 3 & Run 4 & Run 5 \\
\hline Muskingum X & 0.5 & 0.5 & 0.3 & 0.2 & 0.3 & 0.2 & 0.3 \\
\hline Muskingum K (h) & 4.8 & 4.8 & 4.8 & 3 & 2 & 4 & 4.8 \\
\hline Initial deficit (mm) & 90 & 90 & 90 & 90 & 90 & 120 & 100 \\
\hline Maximum deficit (mm) & 230 & 230 & 230 & 230 & 200 & 180 & 210 \\
\hline Constant rate $(\mathrm{mm} / \mathrm{h})$ & 19 & 19 & 19 & 19 & 19 & 30 & 16 \\
\hline lag time (min) & 520 & 520 & 520 & 520 & 520 & 520 & 520 \\
\hline impervious surface $\%$ & 3 & 3 & 3 & 3 & 1 & 3 & 3 \\
\hline NSE & 0.71 & 0.61 & 0.16 & 0.22 & -4 & -7 & 0.322 \\
\hline $\mathrm{RV}_{\mathrm{E}} \%$ & 19 & 12 & 44 & 62 & 50 & 66 & 65 \\
\hline
\end{tabular}

coincides with that month being the latest month of the dry season that starts in mid-April.

\section{Relating land conversion to dam levels and simulated runoff}

Changes in landcover between the years 1984 and 2013 were compared to dam volumes of the same period. Figure $5 \mathrm{a}-\mathrm{c}$ shows the forest area and bare area changes are highly correlated to changes in reservoir volumes $\left(R^{2}>0.9\right)$. Bare area changes show a high negative correlation $(-0.9097)$ with dam volumes. This indicates a strong inverse relationship between the variables. From the year 1984 to 2013 the forest area has been decreasing and areas under cultivation have increased. This can be attributed to forest areas being converted to cultivated land in the catchment. A decrease in forested areas and increase in cultivated land increases the chance of losses of top soil due to erosion, with the potential for causing dam siltation.

Landsat TM and ETM+ images from 1992 to present were assessed, along with intensive fieldwork. Results show that there is an increase in cultivated area and decrease in forest and shrubs, which could be a contributing factor to the decrease in dam levels.

Figure 6 also shows that there is a relatively higher $r^{2}(0.54)$ for the relationship between area occupied by forest and HEC-HMS simulated flow for the years 1993-2012. The relationship between bare area and flows showed a correlation of 0.51 . Results also show that cultivated area cannot explain the variation in average flows, 
TABLE 7

Water balance for Nyazvidzi catchment

\begin{tabular}{|l|c|c|c|c|c|c|c|c|c|c|c|}
\hline & Jan & Feb & Mar & Apr & Jun & Jul & Aug & Sept & Oct & Nov & Dec \\
\hline Mean & 5.14 & 3.39 & 2.19 & 0.67 & 0.71 & 0.07 & 0.04 & 0.46 & 1.21 & 3.99 & 8.12 \\
\hline St Dev & 4.06 & 3.8 & 1.86 & 1.11 & 0.92 & 0.09 & 0.08 & 0.91 & 1.74 & 2.42 & 5.97 \\
\hline CV (\%) & 79 & 112 & 85 & 166 & 131 & 115 & 187 & 199 & 143 & 61 & 74 \\
\hline
\end{tabular}
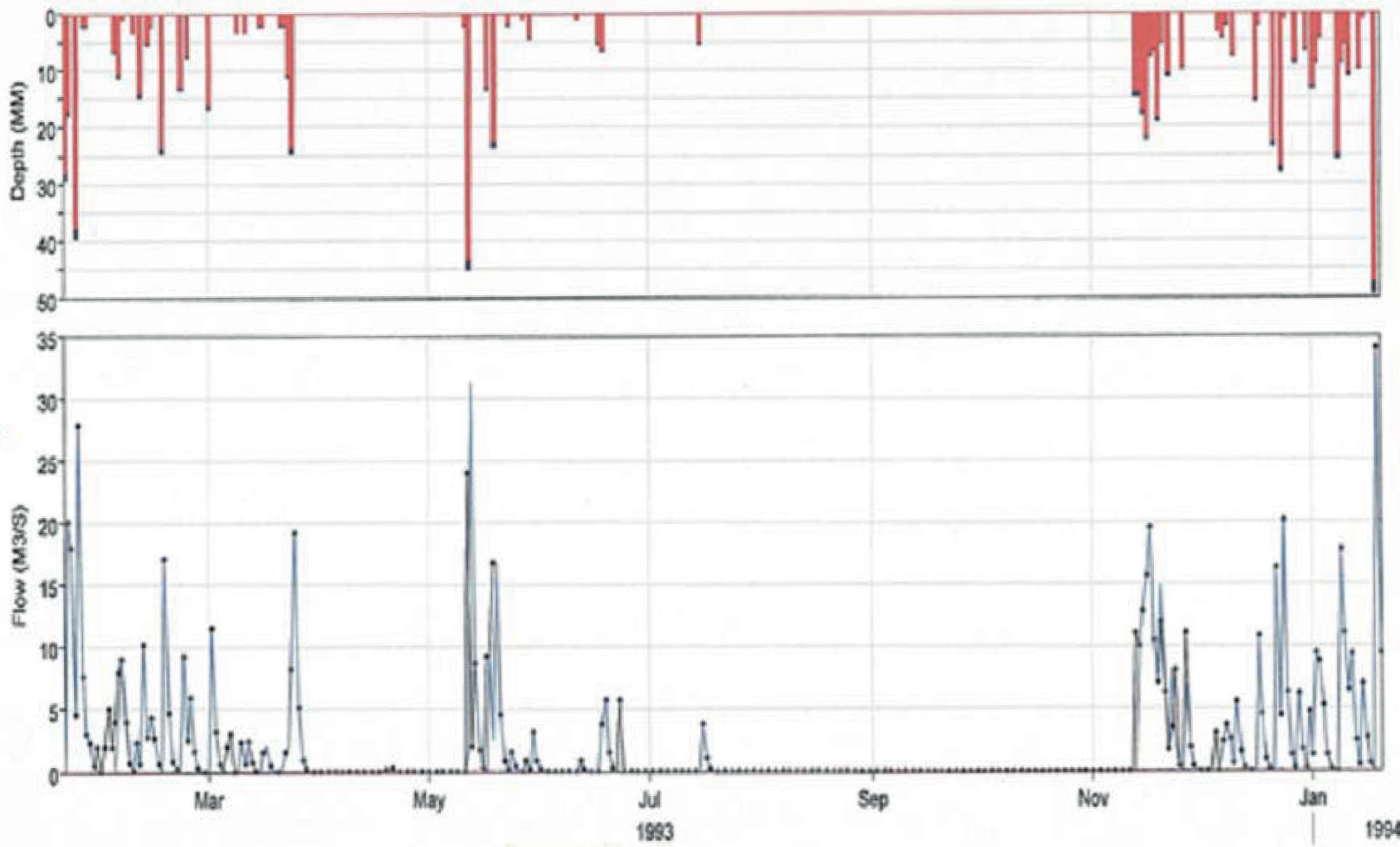

- Precipitation

- Precipitation flow

$\rightarrow \quad$ Observed flow

- Simulated flow

$=$ Base flow

Figure 3

Calibration results for Upper Nyazvidzi sub-catchment (2000-2001)

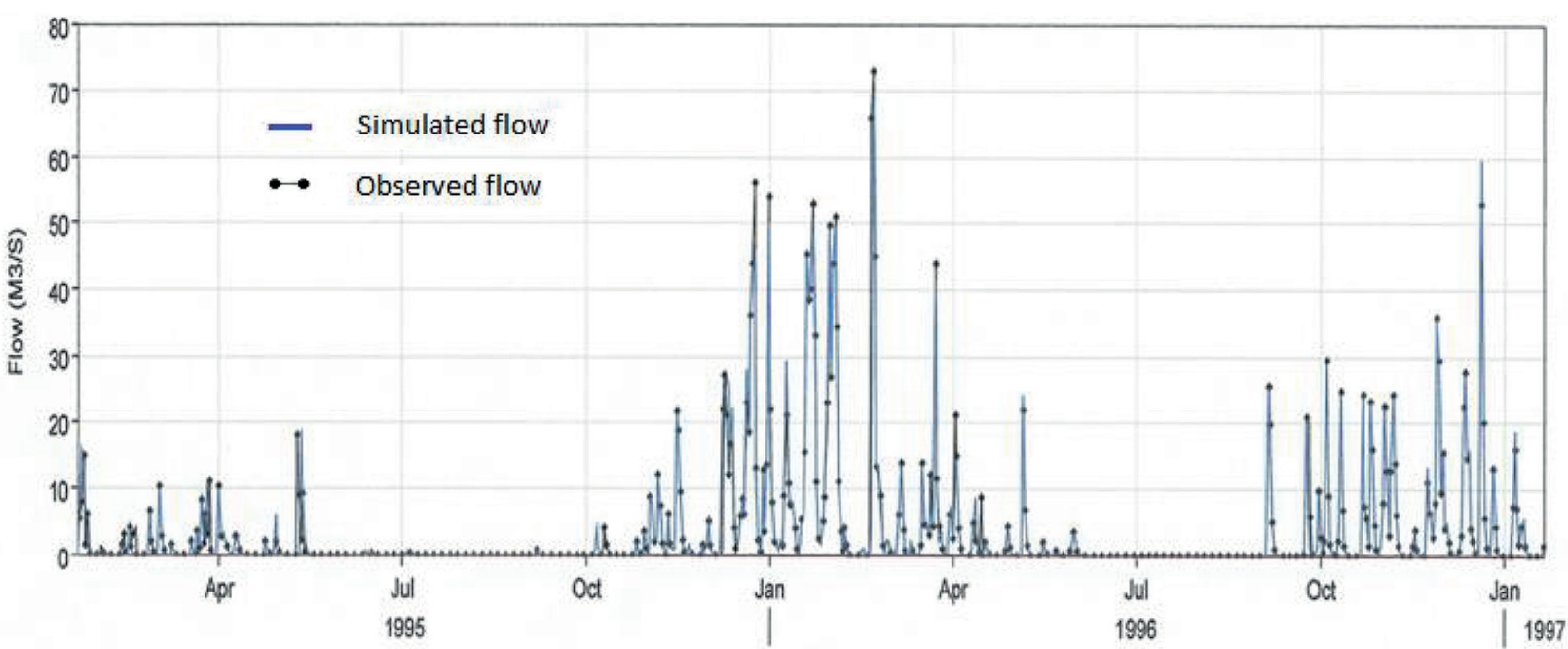

Figure 4

Validation results for Upper Nyazvidzi sub-catchment (1995-Jan 1997) 
as indicated by a poor $r^{2}(0.14)$. The relationships could have been affected by the relatively lower rainfall for the year 2001-2003, which then created a shift to the general expected trend and relation between the bare area, cultivated area and forest area.

\section{CONCLUSIONS}

This study applied GIS, RS and statistical techniques to assess how land-use and landcover changes affect current and future availability of land and water resources of the Upper Nyazvidzi catchment where the Ruti Dam is situated. Four conclusions are drawn from this study.

- Anthropogenic activities, such as cultivation, have caused the decline in vegetation-related classes such as forests and shrubs in the Nyazvidzi catchment.

- The HEC-HMS rainfall-runoff model, whose inputs were prepared with remote-sensing data, satisfactorily simulated runoff in the Upper Nyazvidzi sub-catchment. This proved vital for record extension in this study.

- Significant monotonic decreases were noted in runoff over the study period across monthly to seasonal timescales. This is a cause for concern for the Ruti Dam catchment and the irrigation scheme.

- The relationship between runoff generated with land conversion revealed that that there is a relatively higher $r^{2}$ $(>0.50)$ for the relationship between area occupied by forest and bare area and HEC-HMS simulated flow for the years 1993-2012. Strong relationships $\left(r^{2}\right)$ relating dam levels and land-use classes were obtained: bare (0.95), cultivation $(0.76)$ and forests (0.98).

- The integration of remote sensing and ground data enables water resource managers to adequately quantify and detect environmental changes that may affect availability of water across space and time.
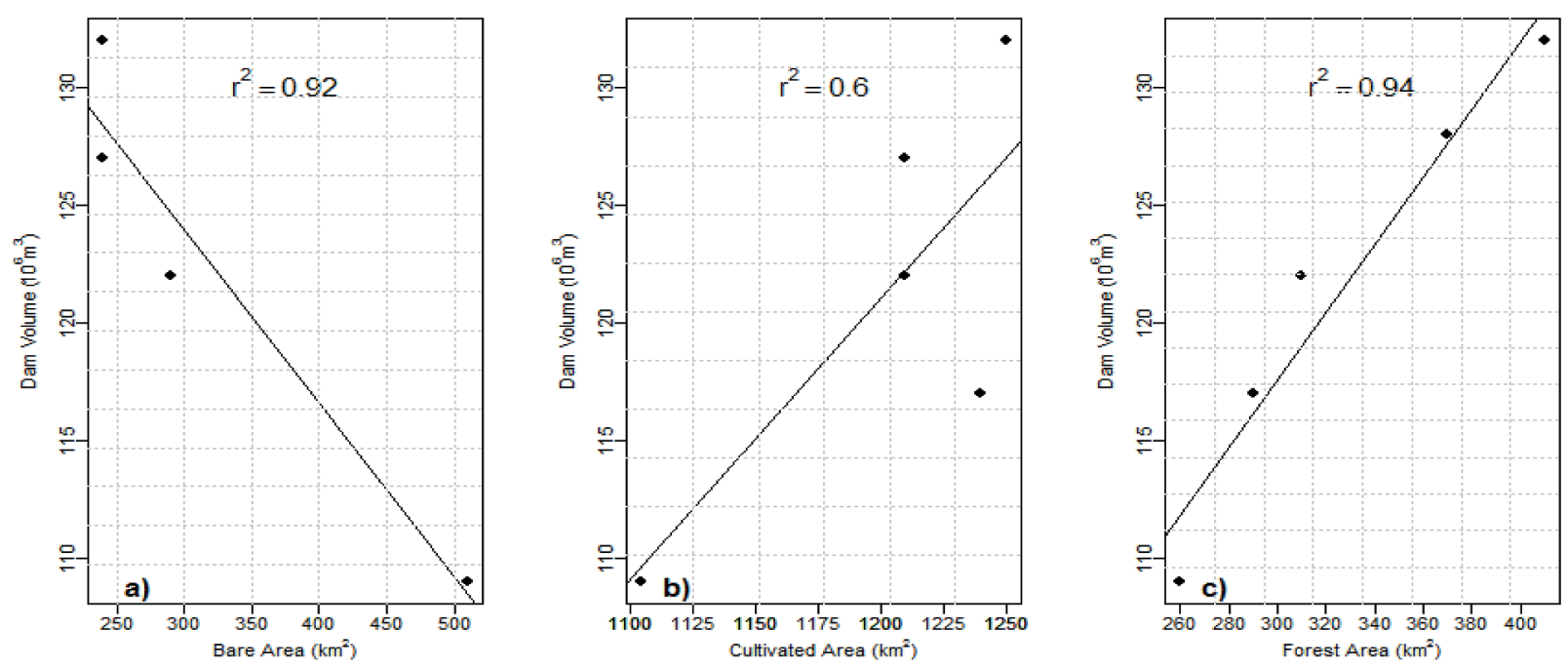

Figure 5

Correlation between dam volume and a) bare area, b) cultivated area and c) forest area for the period 1984-2012
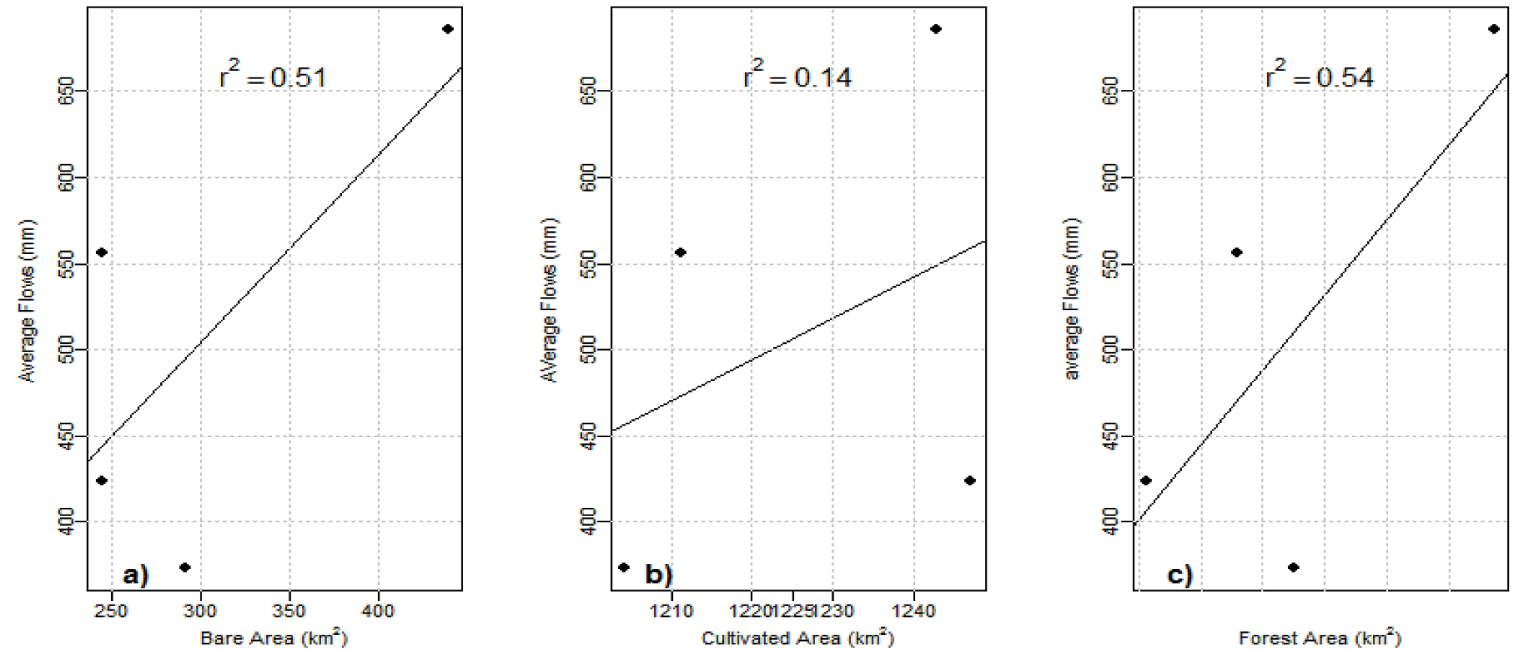

Figure 6

Correlation between average flows and a) bare area, b) cultivated area and c) forest area for the period 1993-2012 


\section{REFERENCES}

ALI M, KHAN SJ, ASLAM I and KHAN Z (2010) Simulation of the impacts of land-use change on surface runoff of Lai Nullah Basin in Islamabad, Pakistan. Landscape Urban Plan. 102 (4) 271-279. https://doi.org/10.1016/j.landurbplan.2011.05.006

CALERA BELMONTE A, MEDRANO GONZALEZ J, VELA MAYORGA A and CASTAO FERNANDEZ S (1999) GIS tools applied to the sustainable management of water resources: Application to the aquifer system 08-29. Agric. Water Manage. 40 (2-3) 207-220. https://doi.org/10.1016/S0378-3774(98)00122-X

CIHLAR J, BEAUBIEN J, LATIFOVIC R and SIMARD G (2005) Land cover of Canada version 1.1. CD-ROM. Natural Resources Canada, Ottawa.

CHEN Y, XU Y and YIN Y (2009) Impacts of land use change scenarios on storm-runoff generation in Xitiaoxi basin, China. Quaternary Int. 208 (1-2) 121-128. https://doi.org/10.1016/j.quaint.2008.12.014

DUBE T, GUMINDOGA W and CHAWIRA M (2014) Detection of landcover changes based on traditional remote sensing image classification techniques, around Lake Mutirikwi, Zimbabwe. Afri. J. Aquat. Sci. 39 (1) 89-95. https://doi.org/10.2989/16085914.2013. 870068

FOODY MG and MATHUR A (2004b) Toward intelligent training of supervised image classifications: Directing training data acquisition for SVM classification. Rem. Sens. Environ. 93 107-117. https://doi.org/10.1016/j.rse.2004.06.017

GUMINDOGA W, RIENTJES HTM, SHEKEDE MD, RWASOKA DT, NHAPI I and HAILE AT (2014a) Hydrological Impacts of urbanisation of two catchments in Harare, Zimbabwe. Rem. Sens. 6 (12) 12544-12574. https://doi.org/10.3390/rs61212544

GUMINDOGA W, RIENTJES THM, HAILE AT and DUBE T (2014b) Predicting streamflow for land cover changes in the Upper Gilgel Abay River Basin, Ethiopia: A TOPMODEL based approach. Phys. Chem. Earth A/B/C 76-78 3-15.

GUMINDOGA W, RWASOKA DT and MURWIRA A (2011) Simulation of streamflow using TOPMODEL in the Upper Save River catchment of Zimbabwe. Phys. Chem. Earth A/B/C 36 (14-15) 806-813. https://doi.org/10.1016/j.pce.2011.07.054

GUMINDOGA W, RWASOKA DT, NHAPI I and DUBE T (2017) Ungauged runoff simulation in Upper Manyame Catchment, Zimbabwe: Application of the HEC-HMS model. Phys. Chem. Earth A/B/C 100 371-382. https://doi.org/10.1016/j.pce.2016.05.002

HABIB E, HAILE AT, TIAN Y and JOYCE RJ (2012) Evaluation of the high-resolution CMORPH satellite rainfall product using dense rain gauge observations and radar-based estimates. J. Hydrometeorol. 13 (6) 1784-1798. https://doi.org/10.1175/ JHM-D-12-017.1

HAILE AT, HABIB E and RIENTJES THM (2013) Evaluation of the climate prediction center CPC morphing technique CMORPH rainfall product on hourly time scales over the source of the Blue Nile river. Hydrol. Process. 27 1829-1839. https://doi.org/10.1002/hyp.9330

HUNDECHA Y and BARDOSSY A (2004) Modeling of the effect of land use changes on the runoff generation of a river basin through parameter regionalization of a watershed model, J. Hydrol. 292 281-295. https://doi.org/10.1016/j.jhydrol.2004.01.002

HORVÁTH S (2002) Spatial and temporal patterns of soil moisture variations in a sub-catchment of River Tisza. Phys. Chem. Earth A/B/C 27 (23-24) 1051-1062. https://doi.org/10.1016/ S1474-7065(02)00141-9

KENDALL M (1975) Rank Correlation Measures. Charles Griffin, London.

LØRUP JK, REFSGAARD JC and MAZVIMAVI D (1998) Assessing the effect of land use change on catchment runoff by combined use of statistical tests and hydrological modelling: Case studies from Zimbabwe. J. Hydrol. 205 (3-4) 147-163. https://doi.org/10.1016/ S0168-1176(97)00311-9
LU D, MAUSEL P, BRONDIZIO E and MORAN E (2004) Change detection techniques International J. Rem. Sens. 25 (12) 2365-2407. https://doi.org/10.1080/0143116031000139863

MAATHUIS BHP and WANG L (2006) Digital elevation model based hydroprocessing. Geocarto Int. 21 (1) 21-26. https://doi. org/10.1080/10106040608542370

MANN HB (1945) Nonparametric tests against trend. Econometrica: J. Econometric Soc. 13 245-259. https://doi.org/10.2307/1907187

MEIER P, FRÖMELT A and KINZELBACH W (2011) Hydrological real-time modelling in the Zambezi river basin using satellitebased soil moisture and rainfall data. Hydrol. Earth Syst. Sci. 15 999-1008. https://doi.org/10.5194/hess-15-999-2011

MUFUTE NL, SENZANJE A and KASEKE E (2008) The development of a risk of failure evaluation tool for small dams in Mzingwane Catchment, Zimbabwe. Phys. Chem. Earth 33 926-933. https://doi. org/10.1016/j.pce.2008.06.029

MUYAMBO A and LACROIX S (2004) Innovative technology contributes to sustainable development at Ruti Dam. Hydro power and dams, ZINWA, Harare.

NASH JE and SUTCLIFFE JV (1970) River flow forecasting through conceptual models. Part I: a discussion of principles. J. Hydrol. 10 282-290. https://doi.org/10.1016/0022-1694(70)90255-6

ONEMA JM, MAZVIMAVI D, LOVE D and MUL M (2006) Effects of dams on river flows of Insiza River, Zimbabwe. Phys. Chem. Earth 31 870-875. https://doi.org/10.1016/j.pce.2006.08.022

RIENTJES THM, MUTHUWATTA LP, BOS MG, BOOIJ MJ and BHATTI HA (2013) Multi-variable calibration of a semidistributed hydrological model using streamflow data and satellitebased evapotranspiration. J. Hydrol. 505 276-290. https://doi. org/10.1016/j.jhydrol.2013.10.006

RWASOKA DT, GUMINDOGA W and GWENZI J (2011) Estimation of actual evapotranspiration using the Surface Energy Balance System (SEBS) algorithm in the Upper Manyame catchment in Zimbabwe. Phys. Chem. Earth A/B/C 36 (14-15) 736-746.

SEARCY JK and HARDISON CH (1960) Double-mass curves. U.S. Geological Survey Water-Supply Paper 1541-B. USGS, Washington.

SHALABY A and TATEISHI R (2007) Remote sensing and GIS for mapping and monitoring land cover and land-use changes in the Northwestern coastal zone of Egypt. Appl. Geogr. 27 (1) 28-41. https://doi.org/10.1016/j.apgeog.2006.09.004

SNYDER FF (1938) Synthetic Unit Graphs. Trans. Am. Geophys. Union 19 447-454. https://doi.org/10.1029/TR019i001p00447

SREENIVASULU V and BHASKAR PU (2010) Estimation of catchment characteristics using remote sensing and GIS techniques. Int. J. Eng. Sci. Technol. 2 (12) 7763-7770.

USACE (2008) HEC-HMS Hydrologic Modeling System User's Manual. Hydrologic Engineering Center, Davis, CA.

VIVONI ER (2007) Variation of hydrometeorological conditions along a topographic transect in northwestern Mexico during the North American monsoon. J. Clim. 20 1792-1809. https://doi.org/10.1175/ JCLI4094.1

WIJESEKARA GN, GUPTA A, VALEO C, HASBANI JG, QIAO Y, DELANEY P and MARCEAU DJ (2012) Assessing the impact of future land-use changes on hydrological processes in the Elbow River watershed in southern Alberta, Canada. J. Hydrol. 412-413 220-232. https://doi.org/10.1016/j.jhydrol.2011.04.018

ZIMSTAT (Zimbabwe National Statistics Agency) (2012a) Census 2012 National Report. ZIMSTAT, Harare.

ZIMSTAT (Zimbabwe National Statistics Agency) (2012b) Provincial Report Masvingo. ZIMSTAT, Harare.

ZIMSTAT (Zimbabwe National Statistics Agency) (2012c) Provincial Report Manicaland. ZIMSTAT, Harare. 